\title{
The Role of Family toward Early Childhood Education through Module: \\ An Approach as Part of Lifelong Learning
}

\author{
Royan Mahmud Musthofa and Kutsiyah \\ Graduate School of Biology Education \\ Universitas Negeri Yogyakarta \\ Jl. Colombo No. 1 Yogyakarta 55281, Indonesia \\ nayor_mm@gmail.com
}

\begin{abstract}
This research aim to propose an approach on how to educate the childhood by focusing the role of parents. The approach with the help of module that can used to be the manual direction of parents in order to giving the early education to their children. Child as a part of the family member are very influenced by the care of their parents to giving education to them. So, that the role of a parent in this case are very important to maximize all of the child's potential. This paper created by literature study. The parenting technique and the characteristic of early childhood education are the topics being focused on. Writer synthesize the characteristics of early childhood education and development, also the benefits of using module for guiding parents. Then make the relationship between both of them to conclude the new strategy or approach in early childhood education by parents. The result is the early childhood education approach based on family through the using of module can guide the parents to wisely educate their children so that it will increase the cognitive, physical, and socioemotional development. This approach strongly recommended to be implicated soon by developing and disseminating product (module which is develop in further research). So, within the use of module, the parents become knowledgeable on how to give the education to their early childhood.
\end{abstract}

Keywords — child's education, family based, module

\section{INTRODUCTION}

Children as one part of the family members were affected by the conditions and the atmosphere there is in the family where the child is grow up. Childhood is a period that will determine the formation of character. Family-based child education is the implementation of the mandate of the Law of the Indonesia Republic Number 20 of 2003 on National Education System in particular article 28, paragraph 5, which reads, "Early childhood education in the form of informal program or family education organized by the education environment."

The family is the smallest social unit in society formed on the basis of commitment to realize the function of families, especially social function and education function. While the definition of early childhood education is a development efforts aimed at children from birth to the age of six years are accomplished by providing stimulation of education to help the growth and development of the physical and spiritual so that children have the readiness to enter further education [1].

Education is a shared responsibility between families, communities and governments. The family is first and main place of education for children. In the family children learn from conception until a child enters the age traveling his own household. Therefore, the family has a fundamental role in optimizing all children's potential.

The family as an informal educational institution are protected in the Law on National Education System. According to Ki Hadjar Dewantara, "The family is the first and eminent educational environment." Thus, the role of the family in terms of education for children, cannot be replaced even if the child has been educated in formal educational institutions and nonformal. To that end, the family must have the ability to carry out the process of improving the nutrition and health, care, upbringing, education and protection.

In a family, of course, a very important role is the father and mother (parents) in educating children. As a parent has to understand what means by education that to educate is not to forbid, giving advice and order the child. But it should be understood that educating is a process of give sense or meaning to the child so that the child can understand the surrounding environment and be able to develop themselves in a responsible manner. The process gives the sense or meaning can be through communication and example/ actions, for example: if you want children discipline, parents can set an example for the child to be things that are good and ethical or parents establish communication with the child dialogic with full disclosure, honesty and sincerity. When we put forward the attitude reigns, advising or prohibit the direct or will not have an impact on the attitudes of children whose style authoritarian and bossy. The parent should not do violent to their child, but based on positive discipline to get the more information about their children's [2].

There is a causal relationship between how parents educate children with what is done for the child. Or supposing what parents spread is what will reap. The role of parents in educating children cannot be replaced completely by the 
institutions of formal schooling or other institutions. Because after all the responsibility of educating children is on the shoulders of parents. In [3] explained that every child is born with the nature of each and dependent family will make the child what is like, like a white paper, parents can freely be willing to give color to the paper. In the process of development of the child, the parents have a strategic role but not many parents who understand and want to take advantage of that role well.

However, the facts of current condition show that how the parents just entrusting their child education only in formal school, e.g., in the kindergarten and or early childhood school. For the carrier parents, it could be hard to spent their time for their child, the spent their time mostly for their job [4]. This situation leads to the lack of caring from parents to child, forming the child development autonomously, without control whether the influence coming from outside, i.e. environment is positive or negative.

According to [5] in the development of child psychology books, dividing the characteristic stages of growth and development of psycho-physical children into three stages, namely; 1) age 1 to 6 of years, 2) age 6 to 8 years, and 3) age 8 to 12 years. Of the three stages at age 1 to 6 years that dominantly determine growth and psycho-physical development of children. Because at this stage of the child's age is characterized as developing moral competence. Based on these characteristics, growth and development of children is still strongly influenced by parents because of the interaction between children and parents is very intense at that age when children are very dependent on their parents.

Stages of cognitive development according to Piaget's theory are: (1) Stage sensorimotor, ages 0-2 years. At this time the child's ability is limited to movements, reflex, discussed the initial, current time and space near the course; (2) preoperational phase, ages 2-7 years. This period of limited ability to receive stimuli. Children begin developing language skills, although his thoughts are still static and not able to think abstractly, the perception of time and space is limited; (3) concrete operational stage, 7-11 years. At this stage the child is able to accomplish the tasks of combining, separating, composing, lined, folding and split; (4) formal operational stage, ages 11-15 years. At this time, the child is capable of high-level thinking, capable of abstract thinking [6].

Thus it can be seen that early childhood is the sensorimotor stage and pre-operational. At this stage the motor sensory abilities of children confined to motion-reflex, discussed the initial, current time and space near the course. While the children are sitting in Kindergarten are in a pre-operational phase.

Vygotsky considers that the social system is very important in the cognitive development of children, parents, teachers, friends interact with children and collaborating to develop an understanding. So, learning occurs in a social context and appear a term of Proximal Development Zone/ Zone of Proximal Development (ZPD). ZPD is defined as a person's potential area children to learn or a stage where capabilities can be enhanced with the help of others more expert [7]. In the next development stage, early childhood learning is done in stages (scaffolding) that help children build prior knowledge and internalize new information recently. Though children learn gradually in accordance with its capabilities [8].

However, the fact found in this community, there are still many families who do not understand this important role. Therefore, it is necessary to have activities to improve the knowledge and skills of the family so that they can provide support to early childhood optimally.

The learning approach is the viewpoint of the learning process that refers to a view of the process that is still common. Facilitate learning approach, inspire, strengthen, and background for determining the method of learning with a particular theoretical coverage. So far we only know two types of learning approaches that are commonly used, namely; (1) approach centered learning or oriented to students (student centered approach) and (2) approach centered learning or oriented to teachers (teacher centered approach). But other than that, in this case we are trying to offer a new approach to learning that children's education is based on the family (child education based family centered approach).

Our major aim in this chapter is propose the new approach on how important the role of the parents to give the education to their early childhood. The parents as the key-point in this approach that is they should maintain their positive influence to their child. The consequence emerged, that is they must be know the guidance on how to educate in good manner. To overcome this consequence, the module is the best way to give the knowledge to the parents. With this approach through the help of module hopefully the parents are knowledgeable of the good education to child so, the child will grow up and develop in their positive character.

\section{THE ROLES OF PARENTS ON DEVELOPING EARLY CHILDHOOD COMPETENCES THROUGH MODULE}

The characteristics of early childhood education are the development of cognitive, physical, and socioemotional [9]. In almost all the country in the world, children begin to formal schooling after they reach the age of 6 years. Their cognitive and socioemotional are already develop. But the period before they enter the formal school is very crucial to be attention.

The process of education and learning in early childhood should be done with the aim of providing a meaningful concept for children through a real experience. The real experience is provided by the parents as caregivers and educators of children. Just experience it is clear that allowing children showed activity and curiosity optimally and locates the position of educator as facilitator and mentor for children. Therefore, the role of parents is very important to give a good example to child so that the child will follow the example of their parents.

In early childhood children experienced a golden age which is a period in which the child begins sensitive / insensitive to receive various stimuli. As described by Vygotsky in the Zone of Proximal Development (ZPD), the child can be upgraded in stages (scaffolding). Through scaffolding with a child's ability can be improved gradually through the help of parents. Thus, the child will be able to build prior knowledge and internalize new knowledge. 
The important issues in the study of children's cognitive development include nature and nurture. Nature refers to an organism's biological inheritance, meanwhile nurture refers to environmental experiences. The parents, once again very influence to the cognitive of the child. Theory exist stated that the child cognitive is depend on how high is the parent's cognitive. The child cognitive would not so far from its parents. Also, the nurture, child at the pre-operational stages will strongly depend on the environment. Because most of the child environment are still close to their parents, so the parents should be created the manipulated or giving example of the good environment to engage the child's development.

\section{discontinuity, and early and later experience.}

Physical development of early childhood emphasizes the motoric activity that is coarser than the fine motoric activity. At an early age children are still like this kind of simple movements like prancing, jumping, and running. They dare to do the activity itself and have the courage to take risks. The role of parents in this regard is to train the motoric skills of children, then parents should frequently to encourage children to do the activity. More to move than just quiet for studying or reading.

Based on [10] revealed that the presence of a parent reduced children's overestimation (i.e., they judge that they can complete physical tasks that are actually beyond their ability [11]). The effect of parental presence persisted over the course of the study for those children whose parents departed after half of the study was complete.

Other aspect, to develop socioemotional of child, the parents' role in this respect can often encourage children to interact with others. Train them to talk to others even if less obvious is how to stimulate the child's socio-emotional ability. But remember that the impression to others that fun will foster the child's confidence to repeat interaction with other people, meanwhile impression one gets children when interacting with other people is bad, then it would also weaken the confidence of the child.

Socioemotional development is influence by the growth of the language and communicative skills because these skills influence the expression of emotion and how emotion is socialized [12]. Parents, to early childhood maintain the important role to train the influence of language and the ability of communication. So, the socioemotional of their child will increase as well as the intensive of training by the parents.

Not all parents have the knowledge of early childhood development in the form of cognitive, physical, and socioemotional. Therefore, we offer a new approach to guide parents to educate and train their children so that they exceed the capability development ZPD [13]. The approach we offer is to guide parents through the module.

\section{THE BENEFITS OF USING MODULE}

The module is one form of teaching materials that are packed full and systematic, are contained within a set of learning experiences are planned and designed to help learners master the specific learning objectives. According [14] found that use of Teaching Module CSAA can improve students' thinking skills. The implementation of Teaching Module CSAA could increase thinking skills as the use of studentcentered approach to encourage students to participate actively in the discovery of knowledge (qualitative data).

Modules are teaching materials were written with the aim that the learner can learn independently with or without the guidance of a person skilled/ knowledgeable. Therefore, the module should contain instructions on learning, competency to be achieved, content key information, training, work instructions, evaluation or feedback on the evaluation [15].

The module serves as a means of learning which is independent, so that the learner can learn independently in accordance with the learning pace of each. Learners who have low learning speed can be many times study modules each learning activity without limited by time, whereas learners high learning opportunities will more quickly learn.

One of the traits or characteristics of the module is to be self-instruction, means that anyone who wants to learn about what is inside the module does not need guidance by instructors who are proficient or companion. People who want to learn can be directly studied independently through the module to know and understand about the explanation contained in the module. Therefore, in this study we are interested in developing a new approach that is based early childhood education or family combined with realized through a module that will be used as a guideline by parents to educate their children at an early age. The using of modular approach is recommended because can increasing performance and achievement so that the modular should be widely used at any level of education [16].

Nowadays, young children are being increasingly exposed to media, technology, and screen time (MeTS) especially at home and also in instructional settings. The teacher is recommended to regarding communication efforts with parents, and MeTS usage in the childcare setting [17]. The parents can use the usage of MeTS to guiding their child. The online module can increase parents' self-reported knowledge. Inside the module there is also a set of assessments to check whether the guidance of parents of children already succeeded or not. The assessment rubric form a judgment about whether the child has reached the points contained in the rubric as proof that they have successfully coaching. With it, parents will be able to evaluate himself [18].

The module has a lot of advantages to serve as guidance material parents in order to educate their children. The module is very suitable to be applied for through modules parents can learn on their own without help from others. Since in this case the parents are no longer able or difficult to learn classical making use of the module is suitable to apply in this case. One of the properties are self-instruction modules into modules advantage in this approach.

The benefit of another module in this approach is the module can be made of various shapes, for example, the module can be uploaded to the Internet so that parents can access the module without being limited by time or space. 
Parents will be easier to assess the module in order to improve their knowledge in conducting the education of their children.

Potential early childhood can be realized if a parent concerned about the development of their children and children are given the freedom to be able to develop a talent or potential. Based on the principles of child development, the early childhood education should be based on the needs of children, which is adjusted to the values espoused in the surrounding environment. Mentoring children adapted physical and psychological development of children, and carried out in an atmosphere of fun play and is designed to optimize the potential of children.

One more point that we want to discuss is to intervention the family will be quietly difficult. So, to solve that problems we would like to recommended the integration of module into the ICT, can in the form of application or program in order to be easy to get, or easy distribution.

\section{CONCLUSION}

The approach of early childhood education based on family through module can be used to be implemented soon in order to giving the parents knowledge about how to wisely educate their child. The using of module can helps the parent to give the knowledge about how the good parenting is. The early childhood development approach based on family which using module can increase the cognitive, physical, and socioemotional development of the children beyond the ZPD. The module gives the much advantages that are selfinstruction, accessible (on-line), and containing the rubrics whether the parent's guiding is success or not.

\section{REFERENCES}

[1] Directorate of Early Childhood Education. Guidelines for the delivery of Early Childhood Education-Based Families. 2012.

[2] Ródenas, F., et al. "Education and Training for Parents Today, Discipline and Wellbeing for Children Tomorrow." Procedia-Social and Behavioral Sciences 116 (2014): 2248-2251.
[3] Saheeh Bukhari Hadith No. 1296 and Sunan Tirmidhi Hadith No. 2064

[4] Priyadna, A., \& Riasti, B. K. Pembuatan istem Informasi Nilai Akademik Berbasis SMS Gateway Pada SMP Negeri 3 Pringkuku Pacitan. IJNS-Indonesian Journal on Networking and Security, 2(2). 2013.

[5] Kartono, Kartini. Perkembangan Psikologi Anak. Jakarta: Erlangga, 2007.

[6] Wadsworth, Barry J. Piaget's theory of cognitive and affective development: Foundations of constructivism . Longman Publishing, 1996.

[7] Papalia, Diane E, Etc. Human Development (Developmental Psychology, translation A. K. Anwar). Jakarta: Kencana Prenada Media Group, 2008.

[8] Vygotsky, Lev Semenovich. Mind in society: The development of higher psychological processes. Harvard university press, 1980.

[9] Slavin, R. E., \& Davis, N. Educational psychology: Theory and practice. New York: Pearson Education, Inc. 2006.

[10] Schwebel, David C., and Marjorie L. Bounds. "The role of parents and temperament on children's estimation of physical ability: Links to unintentional injury prevention." Journal of Pediatric Psychology 28.7 (2003): 505-516.

[11] Plumert, Jodie M. "Relations between children's overestimation of their physical abilities and accident proneness. "Developmental Psychology 31.5 (1995): 866.

[12] Thompson, Ross A., ed. Socioemotional development. Vol. 36. U of Nebraska Press, 1990.

[13] Santrock, J. W. Educational Psychology (Fifth edition). New York: McGraw Hill. 2011.

[14] Sadik, S., and Shazia Zamir. "Effectiveness of Modular Approach in Teaching at University Level." Journal of Education and Practice 5.17 2014.

[15] Prastowo, A. Panduan Kreatif Membuat Bahan Ajar Inovatif. Yogyakarta: DIVA Press. 2012.

[16] Matanluk, Ovelyn, et al. "The Effectiveness of Using Teaching Module based on Radical Constructivism toward Students Learning Process." Procedia-Social and Behavioral Sciences 90 (2013): 607-615.

[17] Sharkins, Kimberly A., et al. "Preschool Children's Exposure to Media, Technology, and Screen Time: Perspectives of Caregivers from Three Early Childcare Settings." Early Childhood Education Journal (2015): 18 .

[18] Camden, Chantal, et al. "Using an evidence-based online module to improve parents' ability to support their child with Developmental Coordination Disorder." Disability and health journal 9.3 (2016): 406415. 